\title{
Investigating the Relationship between Iranian EFL Learners' Cultural Intelligence and their Home Cultural Attachment
}

\author{
Zeinab Azizi \\ International Campus of Ferdowsi University of Mashhad, Iran \\ zeinab.azizi@stu.um.ac.ir \\ Azar Hosseini Fatemi (Corresponding Author)
}

Associate Professor, Ferdowsi University of Mashhad, Iran frj@ferdowsi.um.ac.ir

Reza Pishghadam

Professor, Ferdowsi University of Mashhad, Iran pishghadam@um.ac.ir

\section{Zargham Ghapanchi}

Associate Professor, Ferdowsi University of Mashhad, Iran ghabanchi@ferdowsi.um.ac.ir

Doi:10.5901/mjss.2015.v6n3s1p575

\section{Abstract}

This study was designed to determine whether there is any association between Iranian EFL learners' Cultural Intelligence (CQ) and their Home Culture Attachment (HCA). For this aim, 201 EFL learners containing 135 female and 66 male studying in different institutes of Borujerd took part in this study. Also, the effects of both age and gender on their Cultural Intelligence were examined. They were asked to complete the 5-point Likert scale of CQ and 4-point Likert scale of HCA. The results of correlational study indicated a significant relationship between CQ and some of sub-scales of HCAS. Then, it was estimated that there is a statistically significant difference between male and female subjects with regard to their CQ but there is no statistically significant difference among the age groups with regard to their $C Q$.

Keywords: Cultural Intelligence (CQ), Factors of Cultural Intelligence, Home Culture Attachment.

\section{Introduction}

The concept of cultural intelligence (CQ) is to reflect the ability to contact effectively with people from different cultural settings (Earley, 2002; Earley \& Ang, 2003). This definition is in a line with the fundamental definition of CQ with Earley and Ang (2003), the capacity to interrelate efficiently with people who are culturally different. This can be seen as the ability to create suitable behavior in a new cultural background (Earley, 2002). On the other hand, CQ is adapting and adjusting to the cross-cultural communication background (Sternberg, 1997b). So, the ability to adapt the cross-cultural context is essential in cross-cultural interaction. After that, people can find an appropriate behavior in their contact with others from different cultures.

Cultural intelligence can also be introduced as a quantitative scale of individual difference along which people behave with others in different cultural context (Earley, 2002; Earley and Ang, 2003; Thomas and Inkson, 2003). Triandis (2006) stated that CQ is the ability to delay judgment of a state and situation until different signs of that special state or situation can be assessed and also it is the capability to unify the information obtained from that situation. Early and Ang, (2003) demonstrated that individuals who have a high level of CQ will definitely have a strong mastery of emotional display and physical attendance. Hofstede (1981) introduced significant steps in developing CQ. The main stages that lead to an understanding of others are improvement of a person's range of awareness (Sternberg, 1997b).

In our postmodern world today, according to (Shahsavandi, Ghonsooly,and Kamyabi ,2010) knowledge of the 
world's languages and cultures is becoming more vital and fundamental. Accordingly, there are two aspects: one, home culture (the native culture of the learner) and the other, foreign culture (the culture of the foreign language). In learning a foreign language the concept of home culture attachment and its effects on learning that language becomes vital (Mansoor, 2002). According to Risager (2007), there are three important definitions to keep in mind: 1) Enculturation which is the process of learning one's native culture. 2) Acculturation- which is the process of learning a second culture. 3) Deculturation - which is alienation from home culture due to factors such as mimicry of foreign behavior or accent.

Crucial objective of the present research is to determine whether there is any relationship between Iranian EFL learners' Cultural Intelligence (CQ) and their Home Culture Attachment (HCA).

\section{Theoretical Framework}

\subsection{Cultural intelligence (CQ)}

According to Earley (2002), Cultural intelligence (CQ) is the capability to interact effectively with people who are culturally different from us. In fact, Cultural intelligence (CQ) can be seen as a reliable predictor of performance and modification in multicultural backgrounds. Thomas and Inkson (2003) suggested that CQ is a multidimensional competence composing of knowledge of other cultures, mindfulness, and a set of behavioral skills. Thomas and Inkson (2003) believed that people are able to understand different cultural rules and customs and also they are able to function effectively and appropriately in cross-cultural settings by CQ. According to Earley (2002), CQ is a culture-independent construct that is appropriate to particular cultural backgrounds. In this regard, CQ helps people adjust themselves to various cultural settings. In fact, CQ refers to the capacity to connect in a set of behaviors using skills that are language or interpersonal skills as well as qualities such as tolerance for ambiguity or flexibility that are tuned properly to the culture-based values and manners of the people with whom one interacts (Thomas and Inkson, 2003).

There are two meanings for cultural intelligence based on Brislin (1981). One meaning for cultural intelligence is a set of behaviors that are perceived as intelligent in a particular culture and the other meaning is the ability to adapt oneself to other cultural settings and/or rules. Then, they have suggested that these two interpretations of CQ are associated because intelligence, in its general sense, can help people adapt their behaviors in their experience with people from different cultures.

Cultural intelligence or CQ like individual's intelligence quotient can be assessed on a scale (Thomas \& Inkson, 2003). People who have higher CQ, they are definitely more successful in adapting with any environment and using more efficient business practices, in comparison with people who have lower CQ (Earley, 2002). Accordingly, CQ is consistent forecaster or interpreter of performance in multicultural contexts. According to Thomas \& Inkson (2004), three important objectives should be obtained that the concept of $C Q$ will be constructive and helpful. An important aim is establishing the theoretical context that links measurements of $\mathrm{CQ}$ to psychological and behavioral processes. Then, the definition of CQ should be definite, clear and unambiguous. Consequently, CQ should be tested in order to compare and contrast this new construct with other facets of intelligence and related constructs (Earley \& Ang, 2003).

It is supposed that CQ is related to personality such as emotional intelligence (Law, Wong, \& Song, 2004). Additionally, there are some different aspects of CQ that may be situation specific (Ruzgis \& Grigorernko, 1994). However, empirical exploration of this possibility is required. At last, it is possible that someone with high CQ perform sensitive behavior just as a person with a high IQ that sometimes appears stupid (Hyman, 2002). The circumstance in which this might occur requires more examination. Besides, individual differences in motivations and purposes may determine how it is used while CQ is regarded as a positive capability, just as in other types of intelligence (Hyman, 2002).

There have been identified a number of measurement tools that might relate to one or more of the components (Ang, Van Dyne, Koh, \& Ng, 2004), any kind of evaluation of CQ rests on an assumption of the domain of the construct. The definition of $\mathrm{CQ}$ as a system of interacting capabilities proposes active and dynamic forms of tests (Sternberg, 1997b). A kind of psychometric context is necessary in order to define the operationalization and measurement of CQ. The most crucial point is that the measurement construct should be defined in such a way that, construct bias is not introduced (Ang, Van Dyne, Koh, \& Ng, 2004). On the other hand, if CQ suffers from cultural bias, its value and utility declines because CQ is inherently multicultural construct (Boyacigiller \& Adler, 1991). Of course, there are individual differences in this regard, for example, individuals may have the same proficiency but rate themselves in a different way since their expectations and self-awareness differ. In fact, building CQ is a never-ending process for continual improvement regardless of how people assess themselves on the indicators of CQ (Boyacigiller \& Adler, 1991).

Cultural Intelligence Scale was constructed on a 5-point Likert scale ranging from 1 (strongly disagree) to 5 
(strongly agree) (See Appendix I). It consists of 20 items which is consisted of both positive and reverse coded items. According to Triandis (2006) there are four important elements that affect on CQ: CQ-Strategy, CQ-Knowledge, CQ-Motivation, and CQ-Behavior.

\subsection{Home Culture Attachment}

Attachment theory as formulated by Bowlby $(1969,1973$, and 1980) signifies a body of work that efforts to clarify the pervasiveness of human social attachments and reactions to their disruptions. Early attachment research focused on the connection between children and their caregivers and documented qualitative differences in attachment patterns; three patterns were also distinguished: secure, avoidant, and ambivalent. Following Bowlby's (1973) formulation that attachment relationships are central throughout the life span, researchers soon turned their attention to adult attachment. Adult analogues of children's attachment styles have since been identified (Bowlby, 1980).

According to Keller (2012), the formulation of attachment theory was a significant milestone in the scientific history of the study of human development. The publication of John Bowlby's trilogy of "Attachment and Loss," with the first volume "Attachment" being published in 1969, begins to develop a scientific theory that influenced not only basic research but also various fields of application substantially. On the other hand, Attachment theory is a cooperative effort of John Bowlby and Mary Ainsworth. Ainsworth \& Bowlby (1991) perceived different concepts from ethnology, cybernetics, information processing, developmental psychology, and psychoanalysis. In fact, there is a long history behind the development of attachment theory. Keller (2012) states that students of attachment theory claim a "cultural origin" for attachment theory based on Mary Ainsworth's (1967) Uganda study, which represented her recognition of cultural influences.

English language learning has created a new learning environment for learners to improve their own abilities (Pishghadam \& Zabihi, 2012). In this field, there is a scale which has been designed by Pishghadam and Kamyabi (2009) to measure an individual's attachment to their home culture. This scale shows uni-dimensionality of CQ and determines its fundamental factors that reveal the dominant aspects and factors in home culture attachment.

Home Culture Attachment scale was constructed on a 4-point Likert scale ranging from 1 (strongly disagree) to 4 (strongly agree). It consists of 36 items. The scale is consisted of both positive and reverse coded items concerning different factors.

This study was set out to answer the following questions:

Q1) Are there significant relationships between students' cultural intelligence and their Home Culture Attachment (HCA) regarding all its subscales?

Q2) Are there significant relationships between students' cultural intelligence and their age and gender?

The primary objective of this study is to aim at finding out the relationships between Iranian EFL learners' cultural intelligence and their cultural attachment with all its subscales. In today's increasingly global and diverse work settings, the capacity to function effectively in multi-cultural situations is important for employees, managers, and organizations. Knowledge of one's Cultural Intelligence affords insights about your capabilities to cope with multi-cultural situations, engage in cross-cultural interactions appropriately, and perform effectively in culturally diverse work groups. Knowledge of the Cultural Intelligence of others provides insights about how best to interrelate with others in multi-cultural situations, engage in cross-cultural interactions appropriately, and perform effectively in culturally diverse work groups.

Individuals from different cultures process information differently. Also, individuals from similar cultures have a collective mental programming that they share with other members of their nation, region or group. According to the results of this study by focusing on enhancing social perception and attributional complexity, marketing decision makers can receive more successful results in their own business. It also seems to have positive effect on international marketing decision makers to predict employees' behaviors to organize their plans.

\section{Methodology}

\subsection{Participants}

The total population participating in this study included 200 advanced English language learners overall, 115 of who were female and 85 male whose age varied from 26 to 38. All were Iranian EFL learners studying at different institutes in Borujerd. For this study, advanced students were chosen some of whom were teachers as well. So, they had quite 
enough experience in language learning to be able to give their views. The present methodology was chosen because the advanced EFL learners in institutes have all passed placement tests and it can be regarded as a kind of certainty for being in the same level. Also, the following instruments named CQ questionnaire and HCAS questionnaire used to measure an individual's intelligence quotient and home cultural attachment.Also, validity and reliability of both questionnaires were measured by previous authors and researchers in their articles as well.

\subsection{Instruments}

In order to collect the data in this study, the participants were asked to fill out two questionnaires: CQ questionnaire and HCAS questionnaire. Cultural intelligence or CQ is measured on a scale, similar to that used to measure an individual's intelligence quotient. People with higher CQ's are regarded as better able to successfully unify into any situation. CQ is assessed using the academically validated assessment created by Linn Van Dyne and Soon Ang. Research demonstrates that $\mathrm{CQ}$ is consistent predictor of performance in multicultural settings. For the concept of $\mathrm{CQ}$ to be useful, the theoretical context that links measurements of CQ to psychological and behavioral processes must be established. Although a conceptual definition is beginning to take shape (e.g., Earley, 2002; Earley \& Ang, 2003; Thomas \& Inkson, 2004), it is important that the definition of CQ be clear and unambiguous. Therefore, it is important that CQ be tested in the existing literature to compare and contrast this new construct with other facets of intelligence and related constructs.

However, it is suspected that CQ is related to personality. The context in which this might occur needs further exploration. In addition, while CQ is presented here as a positive capability, just as in other types of intelligence, individual differences in motives and goals may determine how it is used. While a number of assessment instruments that might relate to one or more of the components have been identified (Ang, Van Dyne, Koh, \& Ng, 2004), any assessment of CQ rests on an assumption of the domain of the construct. The definition of CQ as a system of interacting abilities suggests dynamic types of tests (Sternberg, 1997b).

Cultural Intelligence Scale that distributed among participants was constructed on a 5-point Likert scale ranging from 1 (strongly disagree) to 5 (strongly agree) (See Appendix I). The required time for the scale completion was about 15 minutes. The scale consisted of both positive and reverse coded items to ensure that the participants were not completing it randomly.

According to Pishghadam, Hashemi, and Bazri (2012), HCAS was validated by using Rasch measurement, and the general analysis showed that 6 items have infit and outfit indices outside the acceptable range suggested by McNamara (1996, cited in Pishghadam \& Kamyabi, 2009); consequently they were removed from the questionnaire. This questionnaire comprises 36 items with the reliability of 0.85 . About 15 minutes is enough to answer this questionnaire. This scale is a four-point Likert scale, ranging from (1) "strongly disagree" to (4) "strongly agree". The scoring of some of the items should be reversed because of having both positive and negative statements.

In a research by Pishghadam, et al. (2013), EFA was used to prove the validity of HCAS. At first, the internal consistency of the whole scale was evaluated with the Cronbach Alpha reliability estimate. Moreover, using the Cronbach Alpha, the reliability of each factor constructing the validated questionnaire was also inspected. Then, Principal Component Analysis (PCA) extracted the underlying factors by calculating the eigenvalues of the matrix greater than 1.0. To decide about the number of factors to keep for rotation the Scree test was used. To conduct factor rotation, Varimax (orthogonal rotation) with Kaiser Criterion was used. Also, SEM was used to predict the casual relationship between diverse factors of this questionnaire. Then, a theoretical model was identified, consisting of two sets of variables: observed variables characterizing the collected data, and latent variables characterizing the hypothetical constructs assumed to be related to other factors (Pishghadam, et al. 2013). The underlying factors of Home Culture Attachment Scale (HCAS) assessed religious attachment, western attachment, Iranian attachment, cultural attachment, and artistic attachment.

\subsection{Procedure}

Participants of the present study were chosen from those language learners of different institutes in Borujerd who have passed placement test. These participants were in advance level of each institute. So there is a kind of homogeneity among all participants because all of them have passed the same placement test. They took part in the present study after their class hours or in the break time between classes. Collection of the data happened from April to June of 2014. Indeed, the respondents had to indicate their extent of agreement on the 5-Likert Scale of cultural intelligence scale. To find the relationship between Iranian EFL learners' cultural intelligence and their cultural attachment another questionnaire called Home Cultural Attachment Scale (HCAS) was distributed among certain participants in the second 
phase as well. After collecting the data, it was entered and processed with SPSS 16 program. In order to answer the research questions, Pearson Product-Moment Correlation Formula was used.

\section{Results}

The first research question of this study to be dealt with was whether there is a significant relationship between students' cultural intelligence and their Home Culture Attachment (HCA). Therefore, this relationship was put to test by means of Pearson Product-Moment Correlation Formula.

First, the relationship between cultural intelligence and total cultural attachment was assessed. Results can be seen in Table 1 as this Table shows, there is no significant relationship between CQ and cultural attachment $(r=-.03$, p>.05).

Table 1. Correlations between CQ and Home Culture Attachment subscales.

\begin{tabular}{|c|c|c|c|c|c|c|c|}
\hline \multicolumn{2}{|c|}{} & HCA & Religious A & Western A & Iranian A & Cultural A & Artistic A \\
\hline \multirow{3}{*}{ CQ } & Pearson Correlation & -.030 & -.102 & -.034 & -.101 & $.188^{\star}$ & .056 \\
\cline { 2 - 8 } & Sig.(2-tailed) & .750 & .271 & .715 & .275 & .044 & .549 \\
\cline { 2 - 8 } & $\mathrm{N}$ & \multicolumn{6}{|c|}{201} \\
\hline
\end{tabular}

Then, the relation between $\mathrm{CQ}$ and each of the subscales of cultural attachment was examined. According to table there is no significant relationship between CQ and religious attachment $(r=-.10, p>.05)$. Correlation between CQ and Western Attachment shows that there is there is no significant relationship between CQ and western attachment $(r=-.03, p>.05)$. Then, the relation between CQ and Iranian attachment was studied. As Table 1 shows, there is no significant relationship between $C Q$ and Iranian attachment ( $r=-.10, p>.05)$. Continuously, the relation between CQ and cultural shows that there is a positive significant relationship between CQ and cultural attachment $(r=.18, p<.05)$. To see whether there is a significant relationship between students' cultural intelligence and their artistic attachment, Correlations between CQ and Artistic Attachment was examined. As Table 1 demonstrates, there is no significant relationship between CQ and artistic attachment $(r=.056, p>.05)$.

It can be concluded that among the different subscales of home cultural attachment, it was only cultural attachment that was significantly and positively related to $C Q$. Then, to see whether there is a significant difference between male and female subjects, cultural intelligence, independent-samples t-test was run. Descriptive statistics for both males and females can be seen in Table 2.

Table 2. Descriptive statistics for males' and females' CQ

\begin{tabular}{|c|c|c|c|c|}
\hline Gender & $\mathrm{N}$ & Mean & Std. Deviation & Std. Error Mean \\
\hline CQ Female & 135 & 66.43 & 10.140 & .872 \\
Male & 66 & 71.29 & 11.040 & 1.359 \\
\hline
\end{tabular}

As Table 2 indicates, mean of the females' CQ is $66.43(S D=10.14)$ and that of the males is $71.29(S D=11.04)$. To see whether this difference is statistically significant, t-test was run. As the mean of the males (71.29) is higher than that of the females (66.43), it can be said that males have a higher CQ than females.

Table 3. Independent Samples T-Test: Gender with CQ

\begin{tabular}{|l|c|c|c|c|c|c|}
\hline \multirow{2}{*}{ CQ } & \multicolumn{2}{|c|}{ Levene's Test for Equality of Variances } & \multicolumn{4}{c|}{ t-test for Equality of Means } \\
\cline { 2 - 7 } & $\mathrm{F}$ & Sig. & $\mathrm{t}$ & $\mathrm{df}$ & Sig. (2-tailed) & Mean Difference \\
\hline Equal variances assumed & 2.105 & .148 & -2.189 & 199 & .046 & -4.853 \\
\hline Equal variances not assumed & & & -2.147 & 119.784 & .048 & -4.853 \\
\hline
\end{tabular}

As Table 3 indicates, there is a statistically significant difference between males and females with regard to their CQ $t(199)=2.18, p<.05$. As the mean of the males is higher than that of the females, it can be implied that males have a higher CQ than females. 
Table 4. Descriptive statistics for three age groups regarding their CQ.

\begin{tabular}{|c|c|c|c|c|c|c|c|c|}
\hline & \multirow{2}{*}{$\mathrm{N}$} & \multirow{2}{*}{ Mean } & \multirow{2}{*}{ Std. Deviation } & \multirow{2}{*}{ Std. Error } & \multicolumn{2}{|c|}{ 95\% Confidence Interval for Mean } & \multirow{2}{*}{ Min. } & \multirow{2}{*}{ Max. } \\
\cline { 6 - 7 } & & & & & Lower Bound & Upper Bound & & \\
\hline $16-23$ & 63 & 69.54 & 10.616 & 1.337 & 66.87 & 72.22 & 45.00 & 98.00 \\
$24-31$ & 78 & 67.37 & 10.314 & 1.167 & 65.04 & 69.69 & 31.88 & 91.00 \\
$32<$ & 60 & 68.44 & 10.670 & 1.377 & 65.69 .6691 & 71.20 & 45.00 & 90.00 \\
Total & 201 & 68.37 & 10.503 & .740 & 69.83 & 31.88 & 98.00 \\
\hline
\end{tabular}

Students were divided into three age groups, and then their CQ was assessed. These were those whose age ranged between 16 and 23 years old, 24 and 31 years old, and those who were above 32. Descriptive statistics including mean and standard deviation for these three age groups are given in Table 4. As Table 4 indicates, mean of the CQ of those whose age ranged between 16-23 was 69.54, that of those whose age ranged between 24-31 was 67.37, and, that of those whose age was above 32 was 68.44 .

Table 5. One-way ANOVA: Age with regard to $C Q$

\begin{tabular}{|c|c|c|c|c|c|}
\hline & Sum of Squares & $\mathrm{df}$ & Mean Square & $\mathrm{F}$ & Sig. \\
\hline Between Groups & 165.189 & 2 & 82.59 & .747 & .475 \\
\hline Within Groups & 21898.26 & 198 & 110.59 & & \\
\hline total & 22063.45 & 200 & & & \\
\hline
\end{tabular}

To see whether these differences are statistically significant, one-way analysis of variance (ANOVA) was performed. Results can be seen in Table 5. As Table 5 indicates, there is no statistically significant difference among the three groups with regard to their CQ $[F(198,2)=.74, p>.05]$.

\section{Discussion}

The outcome of this investigation to discover the relationship between cultural intelligence and total cultural attachment confirmed that there is no significant relationship between CQ and total cultural attachment $(r=-.03, p>.05)$. But, the relation between $\mathrm{CQ}$ and each of the subscales of cultural attachment was also examined. Among the different subscales of home cultural attachment, it was only cultural attachment that was significantly and positively related to CQ. This conclusion is in the same line with the study by Mahembe, et.,al (2013). The evidence provided in this study shows that the CQS may be an effective cultural intelligence measure that can facilitate empirical cultural intelligence research and practice. The CQS can be used to promote cultural intelligence as a means to enhance both cultural attachment and academic performance through enhanced interaction and communication amongst individuals with different demographic backgrounds.

Then, another conclusion of the present study is finding out the effect of gender on CQ. As the mean of the males (71.29) is higher than that of the females (66.43), it can be concluded that males have a higher CQ than females. This conclusion is in line with the study by Sternberg,et al., (2000). They reevaluated the possible effect of gender on measures of contact quotient (CQ). Finally, they emphasized the influence of gender on one's CQ.

In the next findings of this study that participants' age was divided into three groups of 16-23, 24- 31, and 32 and higher. One-way analysis of variance (ANOVA) indicated that there is no statistically significant difference among the three groups that ranged between 16-23, 24-31 and above 32 with regard to their $C Q[F(198,2)=.74, p>.05]$. This result is in the same line with a study by Thomas and Inkson (2003) who introduced age and gender as control variables related to cultural intelligence. This study doesn't suggest a statistically significant relationship between age and CQ.

\subsection{Implications}

This research project studied to discover the relationship between EFL learners' CQ and their home culture attachment. Also, the significant correlation between participants' age and gender with their CQ were explored. Statistics of the present study indicated that males have a higher CQ than females. But, age of the participants didn't have a significant influence on their CQ. Moreover, among the subscales of home cultural attachment, only cultural attachment had significantly and positively association with CQ. 
Overall, this study aims to advance CQ research and offer practical implications for effectiveness in culturally diverse situations. So, the related scales can also be used in different cultural situations or even multi-cultural states in order to create a certain uniform and consistent condition for both teaching and learning. Following Shaffer et al. (2006), this study considers cultural adaptation an affective outcome because it represents subjective assessments with affective implications. Since intercultural interactions can be stressful, motivational CQ and behavioral CQ have special relevance to cultural adaptation. According to the outcome of this research regarding the relationship between peoples CQ and their gender, it can improve predictions of effectiveness in cross-cultural negotiation and decision making. CQ can also be regarded in the realm of globalization that increasing cultural diversity creates challenges for individuals and organizations. Globalization encourages mobility of labor across national and cultural boundaries. This increases the need to understand cross-cultural multiplicity. By its special scale, the researchers, investigators, traders and economical agents can select the best and more effective one to be succeeded in important international works and responsibilities.

Likewise, it is obvious that ELT has now lots of things to share with other disciplines. It can come to the aid of other disciplines to resolve their problems, and get them to be more expanded. So, the results of this investigation in applied ELT opens new horizons for examiners in different fields of study, showing a novel way of dealing with ELT issues. In addition, the unique setting of English language learning can provide the researchers with more promising areas of research.

\subsection{Limitations of the Study}

The present study is, nevertheless, limited in a number of ways. First, due to feasibility considerations, the participants are to be chosen according to convenience sampling. Second, the participants of the present study comprise EFL students in institutes of Borujerd. So this study should be replicated with samples from other universities or institutes and centers and institutes in different parts of the country and use procedures that ensure a higher degree of randomization and ultimately more generalizability. This can also set the ground for cross comparison of the findings. Third, in this research, the variables in question will be accessed via questionnaires. Using qualitative approaches such interviews, case studies, and observations to investigate these constructs would allow prospect researchers to understand not only if potential interrelationships exist among the constructs, but also the processes by which these constructs develop in the classroom context. Fourth, in the present study only a number of variables such as learners' age and gender will be considered. Other equally important variables such as learners' cultural and socioeconomic background, majors and even economic status are not explored in the present study.

However, the process of gathering data from institutes needs permits from professor of the related classes, so it is a very demanding work. Since the population under study comprises both female and male students, the researcher needs to ask a colleague (a male person) who can help her to gather the data from boys' classes. While filling out the questionnaires by students takes time there may be lack of cooperation on the part of the professors and also unwillingness of students to fill out the forms.

\subsection{Suggestions for Further Research}

Every scientific enquiry opens new directions for further research. Some of the parameters by which research in this domain may be continued are as follows: First other researchers interested in CQ can carry out more investigations on the association between CQ and one's job, habitant, level of education and so on. Second, the relationship between teachers' and professors' CQ of different majors can be compared with each other regarding their specialties. Even the association between their CQ and their pedagogical success can also be a subject for future studies.

In the other realm of this study, home culture attachment of different social classes can be contrasted concerning their habitant, family unit, economical situation and so forth. Also it would be of interest to find out whether home culture attachment as well as CQ affect some traits like anxiety or self confidence. Afterward, the relationship between home culture attachment and social perception or social cognition in other fields can be studied.

Subsequently, what we are as a personality, our motives, objectives, temperaments, and so on, influence what we perceive as a situation. Perception itself will influence our personality. Another study can be conducted to find out how the direction of our behavior depends on the relationship between peoples' social perception and their behaviors. In addition, the effect of social perception on speech and verbal mimicry, facial expression and behavioral matching can be trustworthy for further research. 


\section{References}

Ainsworth, M. D. S. (1967). Infancy in Uganda: Infant care and the growth of love. Baltimore: Johns Hopkins University Press.

Ainsworth, M.D., Blehar, M, Waters, E, \& Wall, S. (1978) Patterns of Attachment: A Psychological Study of the Strange Situation, Hillsdale, NJ: Lawrence Erlbaum, p.282

Ainsworth, M. D. S., \& Bowlby, J. (1991). An ethological approach to personality development. American Psychologist, 46, 333-341.

Ang, S., Van Dyne, L., Koh, C.,\&Ng, K. Y. (2004, August). The measurement of cultural intelligence. Paper presented at the Annual Meeting of the Academy of Management, New Orleans, LA.

Asraf, R. M. (1996). Teaching English as a second or foreign language: The place of culture In English and Islam: Creative Encounters 96. Proceedings of the International Conference (pp. 349-367). Malaysia: International Islamic University Malaysia.

Bazerman, M.H. (2002) 'Cognitions and Behavior in Asymmetric Social Dilemmas: A Comparison of Two Cultures', Journal of Applied Psychology 87: 87-95.

Berry, J. W. (1990). Psychology of acculturation. In J. Berman (Ed.), Cross-cultural perspectives: Nebraska symposium on motivation (pp. 201-234). Lincoln: University of Nebraska Press.

Berry, J. W. (1997). Immigration, acculturation, and adaptation. Applied Psychology: An International Review, 46, 5-34.

Boyacigiller, N. A., \& Adler, N. J. (1991). The parochial dinosaur: Organizational science in a global context. Academy of Management Review, 16(2), 262-290.

Bowlby, J. (1969/1982). Attachment and loss: Vol. 1. Attachment. New York: Basic Books.

Bowlby, J. (1960) 'Separation Anxiety' International Journal of Psychoanalysis, 41: 89-113

Bowlby, J. (1973). Attachment and loss: Vol. 2. Separation: Anxiety and anger. New York:Basic Books.

Bowlby, J. (1980). Attachment and loss: Vol. 3. Loss. New York: Basic Books.

York. Brislin,R.W. (1981).Cross-cultural encounters: Face-to-face interaction.NewYork: Pergamon.

Brown, HD. (2000). Principles of language learning and teaching. (4th Ed.). London: Longman.

Collins, N. L., \& Read, S. J. (1990). Adult attachment, working models, and relationship quality in dating couples. Journal of Personality and Social Psychology, 58, 810-832.

Earley, P. C. (2002). Redefining interactions across cultures and organizations: Moving forward with cultural intelligence. Research in Organizational Behavior, 24, 271-299.

Earley, P. C., \& Ang, S. (2003). Cultural intelligence: Individual interactions across cultures. Stanford, CA: Stanford University Press.

Fraley, R. C., \& Shaver, P. R. (2000). Adult romantic attachment: Theoretical developments, emerging controversies, and unanswered questions. Review of General Psychology, 4(2), 132-154.

Griffin, D. W., \& Bartholomew, K. (1994). Models of the self and other: Fundamental dimensions underlying measures of adult attachment. Journal of Personality \& Social Psychology, 67, 430-445.

Hofstede, G. (1980). Culture's consequences: International differences in work related values. Beverly Hills, CA: Sage.

Hong, Y., Roisman, G. I., \& Chen, J. (2006). A model of cultural attachment: A new approach for studying bicultural experience. In M. H. Bornstein, \& L. Cote (Eds.), Acculturation and parent child relationships: Measurement and development (pp. 135-170). Mahwah, $\mathrm{NJ}$ : Erlbaum.

Hong,Y.,Wan,C.,No,S.,\&Chiu,C.(2007).Multicultural identities. In S. Kitayama, \& D. Cohen (Eds.), Handbook of cultural psychology (pp. 323-345). New York: Guilford.

House, J. (2006). Text and context in translation. Journal of Pragmatics, 38, 338-358.

Hyman, R. (2002). Why and when are smart people stupid? In R. Sternberg (Ed.), Why smart people can be so stupid (pp. 1-23). New Haven, CT: Yale University Press.

Keller, H. (2012). Cross-cultural psychology: Taking people, contexts, and situations seriously. In J. Valsiner (Ed.), The Oxford handbook of culture and psychology (pp. 116-131). Oxford, NY: Oxford University Press.

Kumpulainen, K., \& Renshaw, P. (2007). Cultures of learning. International Journal of Educational Research, 46(3-4), 109-115.

Law, K. S., Wong, C.-S.,\&Song, L. J. (2004). The construct and criterion validity of emotional intelligence and its potential utility for management studies. Journal of Applied Psychology, 89, 483-496.

Mahembe, B., \& Engelbrecht, A.S. (2014). A preliminary study to assess the construct validity of a cultural intelligence measure on a South African sample. SA Journal of Human Resource Management/SA Tydskrif vir Menslike Hulpbronbestuur, 12(1), Art. \#558, 8 pages. http://dx.doi.org/10.4102/ sajhrm.v12i1.558

Mansoor, S. (2002). Culture and teaching of English as a second language for Pakistani students . Retrieved September 23, 2008 from http://www.melta.org.my/ET/2002/wp04.ht

Pishghadam, R., \& Hashemi, M.R., Bazri, E. (2013). Specifying the Underlying Constructs of the Home Culture Attachment Scale. Iranian Journal of Society, Culture \& Language IJSCL, 1 (1), 37-51.

Pishghadam, R., \& Zabihi, R. (2012). Life syllabus: A new research agenda in English language teaching. TESOL Arabia Perspectives, 19(1), 23-27.

Pishghadam, R., \& Kamyabi, A. (2009). The Relationship between accent and deculturationamong EFL learners in Iran. Paper presented at 7th international TELSSI conference, Yazd, Iran.

Risager, K. (2006). Language and culture: Global flows and local complexity. Clevedon, England: Multilingual Matters.

Ruzgis, P.,\&Grigorenko, E. L. (1994). Cultural meaning systems, intelligence, and personality.

Shahsavadi, S., Ghonsooly, B., \& Kamyabi, A. (2010). Designing and validating home culture attachment questionnaire for students of 
foreign languages and its application. Ferdowsi Review, 10(1), 49-76.

Mansoor, S. (2002). Culture and teaching of English as a second language for Pakistani students . Retrieved September 23, 2008 from http://www.melta.org.my/ET/2002/wp04.htm

Sternberg, R.J. (1997b) 'The Concept of Intelligence and Its Role in Lifelong Learning', American Psychologist 52: 1030-7.

Tadmor, C. T., Hong, Y., Chao, M. M., Wiruchnipawan, F., \& Wang, W. (2012). Multicultural experiences reduce intergroup bias through epistemic unfreezing. Journal of Personality and Social Psychology, 103, 750-772.

Tadmor, C. T., Tetlock, P. E., \& Peng, K. (2009). Biculturalism and integrative complexity: Testing the Acculturation Complexity Model. Journal of Cross Cultural Psychology, 40, 105-139.

Triandis, H. C. (2006). Cultural intelligence in organizations. Group and Organization Management, 31: 20-26.

Thomas, D.C. and Inkson, K. (2003) Cultural Intelligence: People Skills for Global Business. San Francisco, CA: Berrett-Koehler.

Wade-Benzoni, K.A., Okumura, T., Brett, J.M., Moore, D.A., Tenbrunsel, A.E. and Bazerman, M.H. (2002) 'Cognitions and Behavior in Asymmetric Social Dilemmas: A Comparison of Two Cultures', Journal of Applied Psychology 87: 87-95.

\section{Appendices}

Appendix I

Cultural Intelligence Scale (CQ)

Name (or Student's Number): Age:

Gender: Major:

Directions: This section contains items. Please read each item and indicate whether you (1) strongly disagree,(2) disagree, (3) neutral, (4)agree, (5) strongly agree.

\begin{tabular}{|c|c|c|c|c|c|c|}
\hline & & & 2 & & & 5 \\
\hline 1 & I am conscious of the cultural knowledge I use when interacting with people with different cultural backgrounds. & & & & & \\
\hline 2 & I adjust my cultural knowledge as I interact with people from a culture that is unfamiliar to me. & & & & & \\
\hline 3 & I check the accuracy of my cultural knowledge as I interact with people different cultures. & & & & & \\
\hline 4 & I know the legal and economic systems of other cultures. & & & & & \\
\hline 5 & I know the rules (e.g., vocabulary, grammar) of other languages. & & & & & \\
\hline 6 & I know the cultural values and religious beliefs of other cultures. & & & & & \\
\hline 7 & I know the marriage systems of other cultures. & & & & & \\
\hline 8 & I know the arts and crafts of other cultures. & & & & & \\
\hline 9 & I know the rules for expressing non-verbal behaviors in other cultures. & & & & & \\
\hline 10 & I enjoy interacting with people from different cultures. & & & & & \\
\hline 11 & I am confident that I can socialize with locals in a culture that is unfamiliar to me. & & & & & \\
\hline 12 & I am sure I can deal with the stresses of adjusting to a culture that is new to me. & & & & & \\
\hline 13 & I enjoy living in cultures that are unfamiliar to me. & & & & & \\
\hline 14 & I am confident that I can get accustomed to the shopping conditions in a different culture. & & & & & \\
\hline 15 & I change my verbal behavior (e.g., accent, tone) when a cross-cultural interaction requires it. & & & & & \\
\hline 16 & I use pause and silence differently to suit different cross-cultural situation. & & & & & \\
\hline 17 & I vary the rate of my speaking when a cross-cultural situation requires it. & & & & & \\
\hline 18 & I change my non-verbal behavior when a cross-cultural situation requires it. & & & & & \\
\hline 19 & I alter my facial expressions when a cross-cultural interaction requires it. & & & & & \\
\hline 20 & I know the political system of other culture. & & & & & \\
\hline 21 & I am interested to get information about leaders and government of other culture. & & & & & \\
\hline 22 & I am stressful when I speak with people from another culture. & & & & & \\
\hline 23 & I enjoy finding differences between my culture and another one. & & & & & \\
\hline 24 & I enjoy gathering data about an unfamiliar culture. & & & & & \\
\hline 25 & I never change my clothing when I interact with other people from other culture. & & & & & \\
\hline 26 & I cannot forget my cultural conventions and & & & & & \\
\hline
\end{tabular}




\section{Appendix II}

Home Culture Attachment Scale

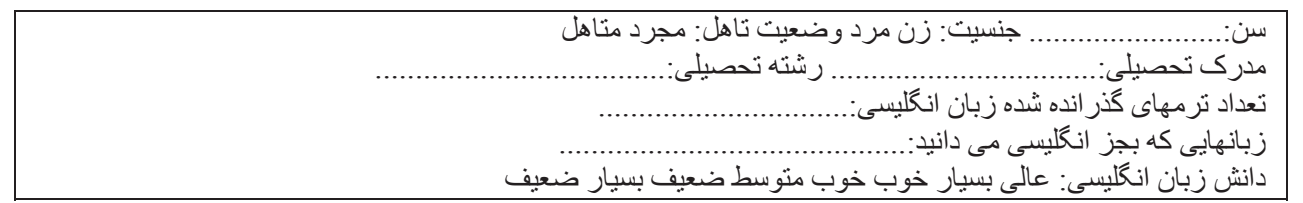

كدام باسخ بشكل بهترى بيانكر نظرات شما مى بانشد؟

\begin{tabular}{|c|c|c|c|c|}
\hline كاملا & 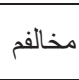 & مو افقم & كاملا مو افقم & \\
\hline & & & & 1.موسيقى غربى (انكليسى/آمريكايى) را بيشتر از موسيقى اير انى دوست دارم. \\
\hline & & & & 2.خو اندن كتابهاى داستانى غربى را به كتابهاى داستانى فارسى تزجيح مى دهم. \\
\hline & & & & 3.بنظر من سبك معمارى اير انى زيباتر از سبك معمارى هاى غربى مى باشّ. \\
\hline & & & & 4.بيشتر ترجيح مى دهم اسامى فرزندانم اسامى غربى باشند تا اسامى اصيل اير انى. \\
\hline & & & & 5.بنظر من فر هنگ و تمدن اير انى يكى از بزركترين تمدن هاى دنيا مى باشد. \\
\hline & & & & 6.فضاى رستور انهاى سنتى را به رستور انهاى مدرن ترجيح مى دهم. \\
\hline & & & & 7.يوشيدن لباس مشكى را بر ایى سوكو ارى مذهبى ضرورى مى دانم. \\
\hline & & & & 8.بنظر من نوروز يكى از بزركترين مر اسم سنتى- ملى در دنبا مى باثند. \\
\hline & & & & 9.نويسندكان اير انى را بهتر از نويسندكان غربى مى شناسم. \\
\hline & & & & 10.بيشتر ترجيح مى دهم فيلم هاى غربى ببينم تا فيلم هاى اير انى. \\
\hline & & & & 11.از شنيدن لهجه هاى محلى اير انى بسيار لذت مى برم. \\
\hline & & & & 12.از كروات/بإيبيون خوشم مى آيد. \\
\hline & & & & 13.فكر مى كنم ادبيات فارسى بسيار غنى تر از ادبيات غربى است. \\
\hline & & & & 14.سفر به مكه را به سفر به ارويا ترجيح مى دهم. \\
\hline & & & & 15.فيلم هاى غربى بِر محتو اتر از فيلم هاى اير انى هستند. \\
\hline & & & & 16.بنظر من موسيقى اصيل اير انى بهترين نوع موسيقى است. \\
\hline & & & & 17.فيلم هاى اير انى بر ايم كسل كننده است. \\
\hline & & & & 18.به كرفتن روزه اعتقاد دارم. \\
\hline & & & & 19.افتخار مى كنم تخت جمشيد در اير ان قرار دارد. \\
\hline & & & & 20.بيشتر غذاهاى غربى خوشمزه تر از غذاهاى سنتى اير انى است. \\
\hline & & & & 21.دادن زكات ر ا لازم مى دانم. \\
\hline & & & & 22.بنظر من زبان انكليسى از زبان فارسى زيباتر و شيرين تر است. \\
\hline & & & & 23.فكر مى كنم فرهنى غربى غنى تر از فر هنگ اير انى است. \\
\hline & & & & 24.فيلم هاى اير انى آموزنده تر از فيلم هاى غربى است. \\
\hline & & & & 25.خريد از مغازه هايى با اسامى غربى بر ايم خوشايند تر است. \\
\hline & & & & 26.ازدو اج با يك آمريكايى/انكليسى را ازدو اجى مناسب مى دانم. \\
\hline & & & & 27. آر ايش موى غربى را مى يِند. \\
\hline & & & & 28.رفنتن به مسجد را مفيد نمى دانم. \\
\hline & & & & 29.به فردوسى، خيام، سعدى و ..... افتخار مى كنم. \\
\hline & & & & 30.مر اسم سنتى ازدو اج اير انى را دوست ندارم. \\
\hline & & & & 31.بنظر من شركت در مر اسم مذهبى ضرورى است. \\
\hline & & & & 32.بركز ارى مهمانى هاى خانو ادگى اير انى ر ا مى بِندام. \\
\hline & & & & 33.يوشيدن لباسهاى با مارك غربى بر ايم خوشايندتر است. \\
\hline & & & & 34.فيلم هاى مستند سنت هاى اير انى را دوست دارم. \\
\hline & & & & 35.زيارت اماكن متبركه را موجب تسكين رو ح مى دانم. \\
\hline & & & & 36.از لباسهاى محلى اير انى خوشم مى آيد. \\
\hline
\end{tabular}

The Underlying Factors of HCAS.

Factor 1. Religious attachment 


$$
\begin{aligned}
& \text { به كرفن به روزه اعتقاد دارم. }
\end{aligned}
$$

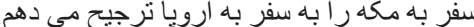

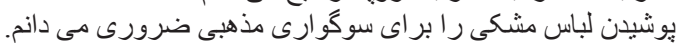

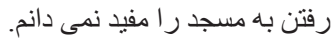

$$
\begin{aligned}
& \text { دادن زكات را لازم مى دانم. }
\end{aligned}
$$

Factor 2. Western attachment

$$
\begin{aligned}
& \text { يو شيدن لباسهاى با مارك غربى بر ايم خوشايندنز است. }
\end{aligned}
$$

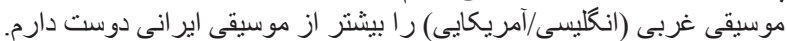

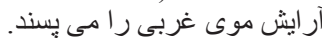

$$
\begin{aligned}
& \text { خريد از مغازه هايى با استامى غربى بر بـ بر ايم خوشايند تر است. }
\end{aligned}
$$

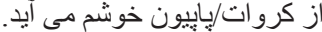

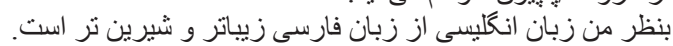

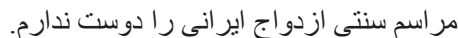

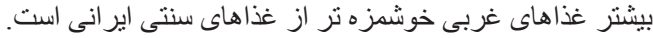

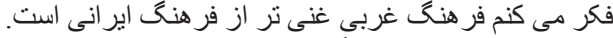

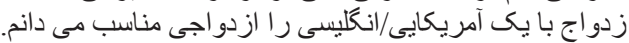

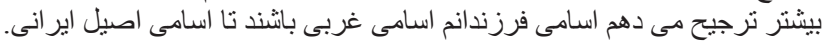

Factor 3. Iranian attachment

$$
\begin{aligned}
& \text { با فردوسى، خيام، سعدى و ..... افتخار مى كنم. }
\end{aligned}
$$

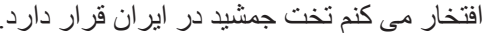

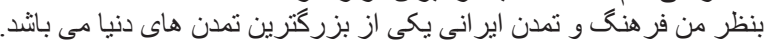

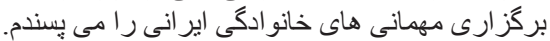

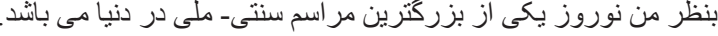

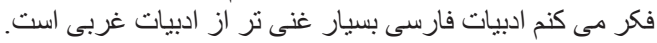

Factor 4. Cultural attachment

$$
\begin{aligned}
& \text { ز لباسهاى محلى اير انى خوشم مى آيد. }
\end{aligned}
$$

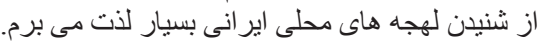

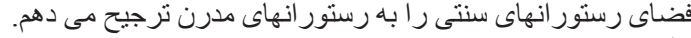

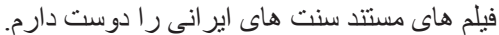

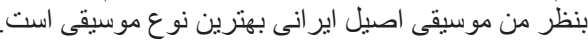

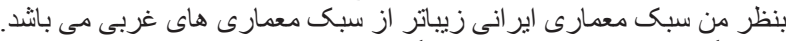

$$
\begin{aligned}
& \text { نويسندكان اير انى را بهتر از نويسندكان غربى أنى مئى شناسم. }
\end{aligned}
$$

Factor 5. Artistic attachment

$$
\begin{aligned}
& \text { خو اندن كتابهاى داستانى غربى را بانه كتابهاى داستانى فارسى ترجيح مى دهم. }
\end{aligned}
$$

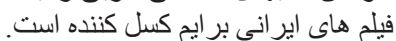

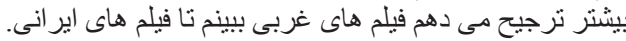

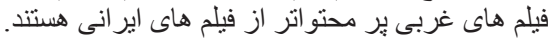

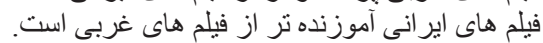

